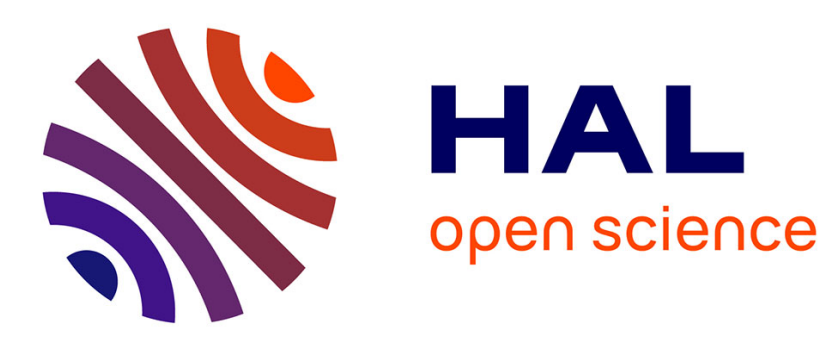

\title{
Development and optimization of a new formaldehyde-free cornstarch and tannin wood adhesive
}

\author{
A. Moubarik, Bertrand Charrier, Ahmed Allal, Fatima Charrier, A. Pizzi
}

\section{To cite this version:}

A. Moubarik, Bertrand Charrier, Ahmed Allal, Fatima Charrier, A. Pizzi. Development and optimization of a new formaldehyde-free cornstarch and tannin wood adhesive. European Journal of Wood and Wood Products, 2009, 68 (2), pp.167-177. 10.1007/s00107-009-0357-6 . hal-00568244

\section{HAL Id: hal-00568244 \\ https://hal.science/hal-00568244}

Submitted on 23 Feb 2011

HAL is a multi-disciplinary open access archive for the deposit and dissemination of scientific research documents, whether they are published or not. The documents may come from teaching and research institutions in France or abroad, or from public or private research centers.
L'archive ouverte pluridisciplinaire HAL, est destinée au dépôt et à la diffusion de documents scientifiques de niveau recherche, publiés ou non, émanant des établissements d'enseignement et de recherche français ou étrangers, des laboratoires publics ou privés. 


\section{䌼 Springer}

Draft Manuscript for Review

\section{Development and optimization of a new formaldehyde-free cornstarch and tannin wood adhesives}

\begin{tabular}{|c|c|}
\hline Journal: & Holz als Roh- und Werkstoff \\
\hline Manuscript ID: & HRW-08-0144.R1 \\
\hline Manuscript Type: & ORIGINALARBEITEN / ORIGINALS \\
\hline $\begin{array}{r}\text { Date Submitted by the } \\
\text { Author: }\end{array}$ & 09-Apr-2009 \\
\hline Complete List of Authors: & $\begin{array}{l}\text { MOUBARIK, Amine; Université de Pau et des Pays de l'Adour, } \\
\text { SYLVADOUR } \\
\text { CHARRIER, Bertrand; Université de Pau et des Pays de l'Adour, } \\
\text { SYLVADOUR } \\
\text { CHARRIER, Fatima; Université de Pau et des Pays de l'Adour, } \\
\text { SYLVADOUR } \\
\text { Allal, Ahmed; Université de Pau et des Pays de l'Adour, Equipe de } \\
\text { physique et Chimie des Polymères } \\
\text { Pizzi, Antonio; Université de Nancy 1, ENSTIB }\end{array}$ \\
\hline Keywords: & $\begin{array}{l}\text { Cornstarch, Formaldehyde, Hexamine, Mimosa tannin, Quebracho } \\
\text { tannin, Wood adhesives, Wood composites }\end{array}$ \\
\hline
\end{tabular}

\section{(5) ScholarONE \\ Manuscript Central}




\title{
Development and optimization of a new formaldehyde-free cornstarch and tannin wood adhesive
}

\author{
A. Moubarik, B. Charrier, A. Allal, F. Charrier, A. Pizzi
}

\begin{abstract}
The development and optimization of a new, environment- friendly adhesive made from abundant and renewable cornstarch and tannin is described in this study. At present, the production of wood composites mainly relies on petrochemical- and formaldehyde-based adhesives such as phenol-formaldehyde (PF) resins and urea-formaldehyde (UF) resins. Formaldehyde-free cornstarch plus tannin adhesives were evaluated for mechanical and physical properties (shear strength, rheological characterisation and thermogravimetric analysis).

First, optimized conditions for the preparation of cornstarch-sodium hydroxide wood adhesives were determined. The parameters studied were the following: total solids content of the adhesives, sodium hydroxide concentration and sodium hydroxide/cornstarch volume ratio. The highest shear strength results appeared to be 0.5 sodium hydroxide / cornstarch volume ratio when using concentrations of cornstarch $\left(65 \% \mathrm{p} / \mathrm{v} \mathrm{H}_{2} \mathrm{O}\right)$ and sodium hydroxide $\left(33 \% \mathrm{p} / \mathrm{v} \mathrm{H}_{2} \mathrm{O}\right)$. The optimum cure temperature was $170^{\circ} \mathrm{C}$ and the cure time $4 \mathrm{~min}$. The addition of two types of tannin-based adhesives, Mimosa and Quebracho, with hexamethylenetetramine (hexamine) hardener to the cornstarch-sodium hydroxide formulation improved the shear strength and decreased the viscosity of adhesives.
\end{abstract}

\section{Entwicklung und Optimierung eines neuen, formaldehydfreien Holzklebstoffes auf Maisstärke- und Tanninbasis}

\section{Zusammenfassung}

In dieser Studie wird die Entwicklung und Optimierung eines neuen, umweltfreundlichen Klebstoffes auf Basis der nachwachsenden und reichlich vorhandenen Rohstoffe Maisstärke und Tannin beschrieben. Gegenwärtig werden zur Herstellung von Holzwerkstoffen Klebstoffe auf Öl- und Formaldehydbasis, wie zum Beispiel Phenolformaldehyd-Harz (PF) und Harnstoffformaldehyd-Harz (UF), verwendet. Die mechanischen und physikalischen Eigenschaften (Scherfestigkeit, rheologische Eigenschaften und thermogravimetrische Analyse) von Klebstoffen auf Maisstärke und Tanninbasis wurden untersucht. 
Zunächst wurden die optimalen Bedingungen zur Herstellung von Maisstärke-NatriumhydroxidHolzklebstoffen bestimmt. Dabei wurden die Parameter Gesamt-Feststoffgehalt der Klebstoffe, Natriumhydroxidkonzentration und das Volumenverhältnis von Hydroxid und Maisstärke untersucht. Die höchste Scherfestigkeit ergab sich bei einem Volumenverhältnis von 0,5 bei einer Maisstärkekonzentration von $65 \% \mathrm{p} / \mathrm{v} \mathrm{H}_{2} \mathrm{O}$ und einer Natriumhydroxidkonzentration von $33 \% \mathrm{p} / \mathrm{v}$ $\mathrm{H}_{2} \mathrm{O}$. Die optimale Aushärtungstemperatur lag bei $170^{\circ} \mathrm{C}$ und die Aushärtungszeit bei 4 Minuten. Durch Zugabe zweier verschiedener Tannin basierter Klebstoffe, Mimosa und Quebracho, mit Hexamin als Härter, zur Maisstärke-Natriumhydroxid-Rezeptur wurde die Scherfestigkeit verbessert und die Viskosität der Klebstoffe verringert.
A. Moubarik ( $\square)$, F. Charrier, B. Charrier
Sylvadour, IUT des Pays de l'Adour, 371 rue du Ruisseau, BP 201, 40004 Mont de Marsan, France. amine.moubarik@etud.univ-pau.fr
A. Pizzi
ENSTIB-LERMAB, Nancy University, Epinal, France

\begin{abstract}
A. Allal
IPREM-EPCP (UMR 5254), Université de Pau et des Pays de l'Adour, Pau, France
\end{abstract}

\title{
1 Introduction
}

One of the main concerns of the $21^{\text {st }}$ century is the environment. The environment has become a subject of constant attention and has become a focal point of our life and welfare (Meyer et al. $1986 \mathrm{a}, \mathrm{b}, \mathrm{c})$.

Formaldehyde-based wood adhesives such as phenol-formaldehyde, urea-formaldehyde and melamin-urea-formaldehyde are derived from petrochemicals, which are non-renewable and therefore ultimately limited in supply ( $\mathrm{Li}$ et al. 2004). Moreover, formaldehyde is considered a priority pollutant by the United States Environmental Protection Agency. Its emission into the environment and exposure of workers at manufacturing facilities continues to be a major safety concern (Keith and Telliard 1979, Myers 1986).

Efforts are made to develop durable adhesives using phenolic substitutes (Thompson 1991). Other investigators have utilized renewable natural polymers to replace phenol in phenolformaldehyde adhesives (Conner et al. 1989, Conner 1989). Lignin, a highly branched natural phenolic polymer and a by-product of the pulping industry, is an abundant renewable resource at 
low cost (Pizzi 2006). Tannin is another example of such a renewable material and has been used to substitute tannin for the synthetic phenolics in wood adhesives (Pizzi 2006).

Starch is one of the most abundant natural polymers (Imam et al. 1999). Starch has been used as an adhesive in a wide range of products, including binders, sizing material, glues and pastes (Imam et al. 1999, Yazaki and Collins 1997). More recently, the development of a starch-based wood adhesive for interior applications has been described (Imam et al. 1999). Starch yields adhesives with excellent affinity for polar materials such as cellulose. Ideally, the contact angle between the adhesive and the substrate should be small. This allows the adhesive to wet the surface and spread uniformly in a thin film with a minimum of voids. In this regard, starch based adhesives wet the polar surface of cellulose, penetrate crevices and pores and, thus, form strong adhesive bonds (Imam et al. 1999).

Among the possible alternatives, tannin is an excellent renewable resource which can be used for replacing petroleum-derived phenolic compounds. The major species from which it can be obtained are Mimosa, Quebracho and Radiata pine. The use of hexamine as a hardener for a tannin, hence, a tannin-hexamine adhesive, is a very environment-friendly proposition. ${ }^{13} \mathrm{C}-\mathrm{NMR}$ has confirmed (Pichelin et al. 1999, Kamoun et al. 2003) that the main decomposition of hexamine under such conditions is not directly due to formaldehyde. It rather proceeds through reactive intermediates, hence, mainly through the formation of reactive imines and iminoaminomethylene bases. ${ }^{13} \mathrm{C}-\mathrm{NMR}$ has also confirmed (Pichelin et al. 1999, Kamoun et al. 2003) that in the presence of chemical species with very reactive nucleophilic sites, such as condensed flavonoid tannins, hexamine is not a formaldehyde-yielding compound. It neither decomposes to formaldehyde and ammonia in an acid environment nor to formaldehyde and trimethylamine in an alkaline environment (Pizzi and Tekely 1995, 1996; Pizzi et al. 1996, Kamoun et al. 2003). The very reactive imines and iminoaminomethylene intermediates initially formed in its decomposition do react with the phenolic species present without ever passing through the formation of formaldehyde (Pizzi and Tekely 1995, 1996; Pizzi et al. 1996; Kamoun et al. 2003).

Initial investigations on the use of wattle tannin in starch corrugating adhesives were carried out at the Division of Forest Products, CSIRO, in 1968. As an alternative material to resorcinol was urgently needed in 1969, the project was extended to include some studies designed to establish reasons for the poor performance of water-resistant starch adhesives (McKenzie and Yuritta 1972). Further research and developments in the field of fortified starch adhesives with wattle tannin were carried out in South Africa (Saayman and Brown 1977). Industrial production with one such system started, however, in South Africa in the late 1970's (Custers et al. 1979). 
In this study, the mechanical properties (shear strength) and physical properties (rheological and thermogravimetric analysis) of cornstarch-tannin adhesives with hexamine as hardener was investigated.

\section{Experimental methods}

\subsection{Preparation of cornstarch-tannin adhesives and preparation of two-ply wood composites bonded with the cornstarch-tannin adhesives.}

Cornstarch water solutions were prepared at six different concentrations namely 12, 25, 50, 65, 75 and $90 \%$, by dissolving cornstarch in deionised water, stirring at room temperature, and adding sodium hydroxide $(\mathrm{Mw}=40.00)$ at different concentrations $(5,15,33,50$ and $75 \%)$ as hardeners. The resulting adhesives were mixed for $45 \mathrm{~min}$ at room temperature and then used for bonding wood veneer.

In order to improve the shear strength of cornstarch-sodium hydroxide adhesives, the two types of tannin, Mimosa and Quebracho, were added in proportions of 5\%, 10\%, 20\%, 30\%, 40\% and $50 \%$ by weight on cornstarch solids content; hardener content used was 5 percent hexamine by weight on tannin extract solids content. The hexamine was dissolved in water to yield a 30 percent concentration solution in water prior to adding to the tannin solution to form the gluemix.

Maritime pine veneer with a thickness of $3 \mathrm{~mm}$ was cut to rectangular specimens $2.5 \times 11.5 \mathrm{~cm}^{2}$ (according to British Standard 1204, 1965, part 2, for synthetic resins adhesives). The adhesive was applied to one side of each piece of veneer. The application area was $2.5 \times 2.5 \mathrm{~cm}^{2}$ for each veneer. The spread rate of the adhesive was $120-150 \mathrm{~g} / \mathrm{m}^{2}$ on a dry weight basis (Nihat and. Nilgül 2002, Pizzi 1977). Two adhesive-coated veneer boards were lapped together with the grain parallel to each other and then pressed at $0.45 \mathrm{MPa}$ (Fig. 1). The press temperature and press time were varied for the determination of their effects on the strength of wood composites. After bonding, the assemblies were conditioned in a Vötsch climate room $\left(25^{\circ} \mathrm{C}\right.$ and $65 \%$ humidity $)$ for 24 hrs. Five hundred samples were prepared for mechanical tests.

\subsection{Mechanical properties}




\begin{abstract}
The shear strength of the wood composite was determined on an Instron testometric M500-50 AT testing machine. The crosshead speed was $1 \mathrm{~mm} / \mathrm{min}$. The load at fraction was measured, and reported as shear strength.

Every experiment was repeated; at least, ten replicates and their standard deviations were calculated.
\end{abstract}

\title{
2.3 Rheological characterization
}

The adhesives were tested with an advanced rheometric expansion system (ARES) with parallel plate's geometry, which was used for all the measurements; the plate diameter used was $25 \mathrm{~mm}$ and the gap between the parallel plates was $1.5 \mathrm{~mm}$. Silicone oil was used to prevent water evaporation.

\subsection{Thermogravimetric analysis (TGA)}

Thermogravimetric analysis (TGA) was carried out with a TGA Q50 thermogravimetric apparatus. Ten milligrams of each cured sample was placed on a balance located in the furnace and heat was applied over a temperature range from room temperature to $600{ }^{\circ} \mathrm{C}$ at a heating rate of $5^{\circ} \mathrm{C} / \mathrm{min}$ in air.

\subsection{Solid phase ${ }^{13} \mathrm{C}$ NMR analysis}

The solid state ${ }^{13} \mathrm{C}$ NMR spectra of the cornstarch, cornstarch- $\mathrm{NaOH}$, mimosa tannin-hexamine and cornstarch-NaOH-MT-H resin systems used, were acquired at ambient temperature by using a Bruker $400 \mathrm{MHz}$ spectrometer. Powdered samples were packed in 4-mm zirconia rotors, sealed with $\mathrm{Kel}-\mathrm{F}^{\mathrm{TM}}$ caps and spun at $6 \mathrm{KHz}$ and at a contact time of $3.5 \mathrm{~ms}$. Chemical shifts were determined relative to tetramethyl silane (TMS) used as control.

\section{Results and discussion}

First, the conditions for the preparation of cornstarch-sodium hydroxide wood adhesives were optimized. Parameters like total solids content of adhesives, sodium hydroxide concentration, 
sodium hydroxide/cornstarch volume ratio, reaction time and reaction temperature were studied. These parameters were varied and their effect on shear strength was studied.

\subsection{Effects of the total solids content of adhesives on shear strength}

The results presented in Table 1 show the effect of cornstarch concentration on shear strength. Table 1 shows that there is an optimum level of cornstarch to be added during formulation to obtain optimal shear strength. As the cornstarch concentration increases, the shear strength and percentage of wood failure increase too. The shear strength increases up to approximately $65 \%$ and remains unchanged with a further increase in cornstarch concentration. A total solid content of $65 \%$ appears to be optimal. Furthermore, the test revealed that in most cases, joint failure was cohesive in the wood (wood failure) and not due to failure either at the interface or of the adhesive itself. It is interesting to note that, when the total solids content was higher than $65 \%$, the cornstarch-sodium hydroxide adhesive became so viscous that it was difficult to apply.

\subsection{Effects of sodium hydroxide concentration on shear strength}

The results of the effect of sodium hydroxide concentration on the shear strength are shown in Table 2. It can be seen from Table 2 that shear strength values and percentage wood failure increase up to a sodium hydroxide concentration of $33 \%$. Beyond this a decrease in shear strength and percentage of veneer failure is observed. It has been shown that the presence of sodium hydroxide accelerates the reaction between the two polymers amylose and amylopectin due to an increase in $\mathrm{pH}$ of the basic medium (Yazaki and Collins 1997; Kennedy 1989; Leach et al.1961; Champagne et al. 1985). It is concluded that $33 \%$ sodium hydroxide concentration is optimal for the preparation of cornstarch-sodium hydroxide adhesives.

\subsection{Effects of sodium hydroxide/cornstarch volume ratio on shear strength}

Table 3 reports the results of the effect of sodium hydroxide/cornstarch volume ratio on shear strengths of wood composites. It is observed that shear strength and percentage of veneer failure increase up to sodium hydroxide/cornstarch volume ratio of 0.5 . Beyond this a decrease in shear 
strength is observed. At higher sodium hydroxide/cornstarch volume ratios, it appears that crosslink formation is hindered, which reduces the rate of crosslink formation and decreases shear strength (Saayman and Brown 1977, Custers et al. 1979).

Comparative solid state CP-MAS ${ }^{13} \mathrm{C}$ NMR spectra of cornstarch and $\mathrm{NaOH} /$ cornstarch were also done. The comparative ${ }^{13} \mathrm{C}$ NMR spectra in Figure 2 show that some low molecular weight compounds were produced. This is evident from the appearance of new peaks in the 18-40 ppm and 127-135 ppm region. The production of these low molecular weight compounds is due to the dissociation of intermolecular hydrogen bonding in the amylopectin (Tako and Hizukuri 2002; Yamamoto et al. 2006).

The alkaline solution reduces the rigidity as well as the stability of the molecular organization of starch. Therefore, the mobility of the amylose chains is increased, which contributes to the loss of granule architecture (Cardoso 2007).

\subsection{Effects of hot-press temperature on shear strength}

In Table 4, the results of the effect of reaction temperature on the preparation of adhesives are shown. The adhesives were prepared at $60^{\circ} \mathrm{C}, 80^{\circ} \mathrm{C}, 120^{\circ} \mathrm{C}, 140^{\circ} \mathrm{C}, 160^{\circ} \mathrm{C}, 170^{\circ} \mathrm{C}, 180^{\circ} \mathrm{C}$ and $200^{\circ} \mathrm{C}$. Shear strength and percentage of veneer failure increase with increasing temperature from $80^{\circ} \mathrm{C}$ to $170^{\circ} \mathrm{C}$, and then decrease (Table 4). It appears that crosslink formation starts at $80^{\circ} \mathrm{C}$. However, at this temperature, the rate and the extent of crosslink formation are low. With the increase in temperature, rate and extent of network formation increase (Mozaffar et al. 2004). This causes the increase in shear strength. With increasing the reaction temperature to $200^{\circ} \mathrm{C}$, a decrease in shear strength and percentage of veneer failure is observed. This appears to infer that $170^{\circ} \mathrm{C}$ is the optimal polymerization temperature.

Using TGA, the thermal decomposition and thermal stability of the adhesive are assessed. Figure 3 shows the TGA curve and its derivative (DTG) of the adhesive at different temperatures. The TGA curve shows that there is an evident mass loss at $175^{\circ} \mathrm{C}$. From this temperature onward the curve decreases initially, indicating cornstarch decomposition. This means that the optimum cure 
temperature was $170{ }^{\circ} \mathrm{C}$. The results obtained by thermogravimetric analysis confirm the results obtained by the shear strength tests.

\subsection{Effects of hot-press time on shear strength}

The shear strength significantly increased when the hot-press time was increased from 2 to 4 min (Table.5). A longer hot-press time means more energy is needed for cross-linking. This is the reason for the improvement of the mechanical properties with increasing press time. Further increase in hot-press time from 4 to 25 min had little effect on the shear strength. With increasing the reaction time to $25 \mathrm{~min}$, a decrease in shear strength was observed. The resin still set but the prolonged reaction time appeared to cause the breakdown of some fraction of the hardened network resulting in a decrease in the shear strength observed (Mozaffar et al. 2004). From the above, it appears that, a reaction time of $4 \mathrm{~min}$ is optimal for the preparation of cornstarch- $\mathrm{NaOH}$ resin.

The results in Figure 4 appear to confirm this. Figure 4 shows the variation of the viscoelastic parameters (G' and G') with time at $170{ }^{\circ} \mathrm{C}, 1 \%$ strain and $1 \mathrm{rad} / \mathrm{s}$. Here, it can be observed that the elastic modulus $\left(\mathrm{G}^{\prime}\right)$ and viscous modulus $\left(\mathrm{G}^{\prime \prime}\right)$ increase progressively with increasing the time up to $4 \mathrm{~min}$. Beyond this a sharp decrease in $\mathrm{G}^{\prime}$ and $\mathrm{G}^{\prime}$ ' is observed. This indicates that the optimum cure time is $4 \mathrm{~min}$. Thus, this rheological characterization confirms the results obtained by the shear strength tests.

\subsection{Improvement of the shear strength with two types of tannin, hardened with hexamine.}

The shear strength of the cornstarch- $\mathrm{NaOH}$ wood adhesives was then improved by addition of two types of tannin-based adhesives, mimosa and quebracho, using hexamine as hardener.

The results of the effect of addition of tannin (Mimosa or Quebracho) and hexamine on shear strength are shown in Table 6. This clearly illustrates that, in both cases, shear strength increases with an increase of the tannin percentage up to $10 \%$. Beyond this level a decrease in shear strength is observed. A decrease in shear strength is attributed to the high amount of hardener (hexamine); which makes the adhesive very viscous. The addition of mimosa tannin and hexamine (Cornstarch-NaOH-MT-H) improves the mechanical properties of $16 \%$ compared to the cornstarch- $\mathrm{NaOH}$ adhesives alone.

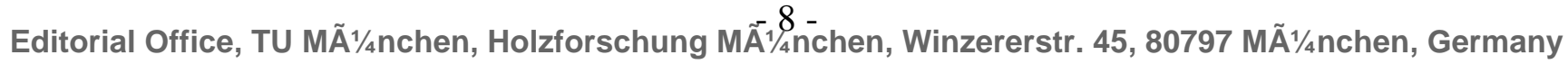


1

2

3

4

5

Pizzi (2006) reported that in the case of Mimosa tannin hardened with hexamine, di- and tribenzylamine bridges were formed, this being stable bridges. Figure 5 shows this mechanism.

In Figure 6, the comparative solid state CP-MAS ${ }^{13} \mathrm{C}$ NMR spectra of cornstarch, $\mathrm{NaOH} /$ cornstarch, mimosa tannin/hexamine and cornstarch-NaOH-MT-H adhesive are shown. The spectra in Figure 6 show that no differences were noticeable between the three solid states CP-MAS ${ }^{13} \mathrm{C}$ NMR spectra of the $\mathrm{NaOH} /$ cornstarch, mimosa tannin/hexamine and cornstarch$\mathrm{NaOH}-\mathrm{MT}-\mathrm{H}$ adhesive. This indicates that the two materials function as a polymer blend rather than co-reacting. One definite interaction is that the use of $\mathrm{NaOH}$ necessary for cornstarch also favours the condensation reaction of mimosa tannin with hexamine (Pizzi 1994).

\subsection{Viscosity of the natural wood adhesives}

The results in Table 7 compare the viscosity of the three natural wood adhesives prepared under their optimal conditions (Cornstarch-NaOH, Cornstarch-NaOH-MT-H and Cornstarch-NaOHQT-H). Viscosity is measured by the advanced rheometric expansion system (ARES) at $25^{\circ} \mathrm{C}$. Table 7 indicates that the addition of tannin (Mimosa or Quebracho) and hexamine to the first formulation (cornstarch- $\mathrm{NaOH}$ ) decreases the viscosity of the natural adhesives. The addition of tannin mimosa and hexamine (Cornstarch-NaOH-MT-H) decrease the viscosity of $25 \%$ compared to the cornstarch-NaOH adhesives (Pizzi 1994; Li and Maplesden 1998).

It is clear that cornstarch-NaOH-MT-H wood adhesive, is the best formulation because it improves the shear strength of $16 \%$ and decreases the viscosity of $25 \%$ compared to the cornstarch- $\mathrm{NaOH}$ adhesives.

\subsection{Comparison of the mechanical properties of cornstarch-tannin adhesives with commercial adhesives}

The cornstarch-NaOH-MT-H adhesive prepared at optimized conditions was compared with three different types of industrial wood adhesives (urea-formaldehyde, polyvynylacetate adhesive and a polyurethane adhesive) for their mechanical properties (Table 8). The results show that the cornstarch-NaOH-MT-H natural adhesive has comparable mechanical properties to the ones of commercial adhesives under the testing conditions used.

\subsection{Effects of moisture and liquid water on shear strength}

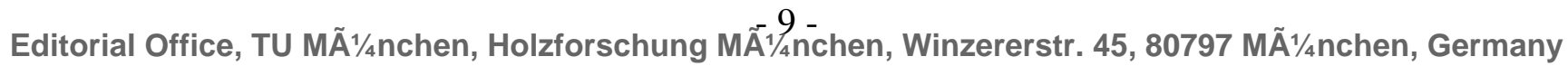


Table 9 shows the effects of moisture $(65,80$ and $90 \%$ relative humidity) on the mechanical properties of cornstarch-NaOH-TM-H, urea formaldehyde, vinyl and polyurethane adhesive. After bonding, the assemblies were conditioned in a Vötsch climate room $\left(25^{\circ} \mathrm{C} ; 65,80\right.$ and $90 \%$ relative humidity) for 7 days. Ten samples were prepared for each resin. It can be seen from Table 9 that Cornstarch-NaOH-TM-H, urea formaldehyde vinyl adhesive and polyurethane adhesive had similar shear strength values at $25^{\circ} \mathrm{C}$ and $65 \%$ relative humidity. Furthermore, the experimental results showed that there was no shear strength deterioration observed between $65 \%$ and $90 \%$ relative humidity. The results indicate that under moisture conditions, formaldehydefree cornstarch-NaOH-TM-H adhesive is capable of giving shear strength results which are comparable to those obtained with synthetic resins.

Data for shear strength after 2 hours immersion in liquid water $\left(\mathrm{pH}=7\right.$ and $\left.25^{\circ} \mathrm{C}\right)$ are summarised in Table 10. After immersion, two-ply wood bonded with cornstarch-NaOH-TM-H resin exhibited poorer values of shear strength compared to samples bonded with the commercial resins (urea formaldehyde, Vinyl and Polyurethane adhesive). These natural adhesives are developed exclusively for interior grade panels, hence for an application different from the traditional tannin adhesives. For this reason their resistance to liquid water has no particular importance.

\subsection{Effects of storage time of cornstarch-NaOH-MT-H adhesives on shear strength}

The cornstarch-NaOH-MT-H adhesive was prepared, and then stored at room temperature for various times before being applied to the wood veneers to determine the effect of storage time on the shear strength of the joint. With increasing storage time, the shear strength decreased (Figure 7). When the cornstarch-NaOH-MT-H adhesives were stored at room temperature for one day, the shear strength was significantly lower than at a storage time of $45 \mathrm{~min}$. The data fitted well the following equation, using the software: 'Table Curve' (2D Windows V2.03).

$$
\sigma=1.56+3.67 \exp \left(-\frac{t}{9.39}\right)
$$


where $\sigma$ is the shear strength ( $\mathrm{MPa}$ ) and the time (days). The adjusted $\mathrm{R}^{2}$ value was 0.99 , indicating a good fit. The decline of shear strength with storage time is still not fully understood.

\title{
4 Conclusion
}

Cornstarch was used with tannin to form a natural wood adhesive. The cornstarch-tannin adhesive is easy to prepare. The adhesive was developed and optimized for wood bonding. In some countries, cornstarch and tannin are inexpensive renewable polymers. The cost of this adhesive appears to be lower than that of the synthetic phenolic resins traditionally used for wood adhesives. Its main advantage is that it contains no formaldehyde or phenol, both of which are considered as environmental pollutants.

Research is in progress to further improve cornstarch-tannin adhesive formulations by employing other nonvolatile, non-toxic aldehyde hardeners (glyoxal or dioxal).

\section{Acknowledgements}

The authors would like to thank the "Conseil Général des Landes" (Aquitaine, France) for providing financial support.

\section{References}

\begin{abstract}
AFNOR (1996) Norme NF EN 113 : Produits de préservation du bois. Méthode d'essai pour déterminer l'efficacité protectrice vis-à-vis les champignons basidiomycètes lignivores. Détermination du seuil d'efficacité.

BS 1204: Part 2 (1965) Synthetic resin adhesives (phenolic and aminoplastic) for wood. Specification for close-contact adhesives British Standards Institution Cardoso $\mathrm{MB}(2007)$ from rice starch to amylose crystals: alkaline extraction of rice starch, solution properties of amylose and crystal structure of v-amylose inclusion complexes. Université Joseph Fourier, Grenoble I, France.
\end{abstract}


Cetin NS, Ozmen N (2002) Use of organosolv lignin in phenol-formaldehyde resins for particleboard production. II. Particleboard production and properties. International Journal of Adhesion \& Adhesives 22, 481-486.

Champagne ET, Rao RM, Liuzzo JA, RobinsonW, Gale RJ, Miller F (1985) Solubility behaviors of the minerals, proteins, and phytic acid in rice bran with time, temperature, and $\mathrm{pH}$. Cereal Chem. 62, 218-222.

Conner AH (1989) Carbohydrates in adhesives: introduction and historical perspective. ACS Symposium series 385, p. 271-288.

Conner AH, Lorenz LF, River BH (1989) Carbohydrate-modified-phenol-formaldehyde resins formulated at neutral conditions. ACS Symposium Series 385. p. 355-369.

Custers PAJL, Rushbrook R, Pizzi A, Knauff CJ (1979) Industrial applications of wattletannin/urea-formaldehyde fortified starch adhesives for damp-proof corrugated cardboard, Holzforsch. Holzverwert., 31(6), 131-133.

Imam SH, Mao L, Chen L, Greene RV (1999) Wood adhesive from crosslinked poly(vinyl alcohol) and partially gelatinized starch: preparation and properties. Starch/Stärke 51 (1999) Nr. 6, S.225-229.

Kamoun C, Pizzi A, Zanetti M (2003) Upgrading melamine-urea-formaldehyde polycondensation resins with buffering additives. I. The effect of hexamine sulfate and its limits. J. Appl. Polym. Sci. 90, 203-214.

Keith IH, Telliard WI (1979) Priority pollutants. Environ Sci Technol; 13:416-23.

Kennedy HM (1989) Starch- and dextrin-based adhesives. In: Hemingway, R.W., Conner, A.H. (Eds.), Adhesives from Renewable Resources. American Chemical Society, Washington, DC, pp. $326-335$. 
Leach VHW, Schoch TJ, Chessman EF (1961) Adsorption von alkaline das stärkekorn. Starke 13 (6), 200-203.

Li J, Maplesden F (1998) Commercial production of tannins from radiata pine bark for wood adhesives. IPENZ Transactions, Vol. 25, No. 1/EMCh, 1998.

Li K, Geng X, Simonsen J, Karchesy J (2004) Novel wood adhesives from condensed tannins and polyethylenimine. International Journal of Adhesion \& adhesives 24, 327-333.

McKenzie AW, Yuritta JP (1972) Starch tannin corrugating adhesives. Appita 26 (1), 30-34. Meyer B, Andrews BAK, Reinhardt RM (1986a) European formaldehyde regulations: a french view. In: Coutrot D(ed) Formaldehyde release from wood products. American Chemical Society Symposium Series No. 385, Washington, D.C., pp 209-216.

Meyer B, Andrews BAK, Reinhardt RM (1986b) Formaldehyde release from wood panel products bonded with phenol from aldehyde adhesives. In: Emery JA (ed) Formaldehyde release from wood products. American Chemical Society Symposium Series No. 385, Washington, D.C., pp 26-39.

Meyer B, Andrews BAK, Reinhardt RM (1986c) Formaldehyde release rate coefficients from selected consumer products. In: Pickrell JA, Griffis LC, Mokler BV, Hobbs CH, Kanapilly GM, Bathija A (eds) Formaldehyde release from wood products. American Chemical Society Symposium Series No. 385, Washington, D.C., pp 40-51.

Mozaffar AK, Sayed Marghoob A, Ved Prakash M (2004) Development and characterization of a wood adhesive using bagasse lignin. International Journal of Adhesion \& Adhesives 24 (2004) 485-493.

Myers GE (1986) Resin hydrolysis and mechanism of formaldehyde release from bonded wood products. In: Wood adhesives in 1985: status and needs. Madison, WI, Forest products Research Society. P.77-80.

Nihat SC, Nilgül Ö (2002). Use of organosolv lignin in phenol-formaldehyde resins for particleboard production. I. Organosolv lignin modified resins. International Journal of Adhesion \& Adhesives. 22 (6), 477-480. 
Pichelin F, Kamoun C, Pizzi A (1999) Hexamine hardener behaviour: effects on wood glueing, tannin and other wood adhesives. Holz Roh- Werkst 57 (5), 305-317.

Pizzi A (1977) Hot-setting tannin-urea-formaldehyde exterior wood adhesives. Adhes. Age 20: $27-35$

Pizzi A (1994) Advanced wood adhesives technology. M. Dekker, New York.

Pizzi A (2006) Recent developments in eco-efficient bio-based adhesives for wood bonding: opportunities and issues. J. Adhesion Sci. Technol., Vol 20, No.8, pp.829-846.

Pizzi A, Tekely P (1995) Mechanism of polyphenolic tannin resin hardening by hexamethylenetetramine: CP-MAS ${ }^{13}$ C NMR. J. Appl. Polym. Sci. 56:1645-1650.

Pizzi A, Tekely P (1996) Hardening mechanisms by hexamethylenetetramine of fast-reacting phenolic wood adhesives - a CPMAS ${ }^{13} \mathrm{C}$ NMR study. Holzforschung 50:277-281.

Pizzi A, Roll W, Dombo B (1996) Hitzehärtende Bindemittel. USA patent 5,532,330

Saayman HM, Brown CH (1977) Wattle-base tannin-starch adhesives for corrugated containers. Forest Prod J 27 (4), 21-25.

Tako M, Hizukuri S (2002) Gelatinization mechanism of potato starch. Carbohydr. Res. 48, 397401.

Thompson GE (1991) Demethyllated kraft lignin as a substitute for phenol in wood adhesives.M.S.Thesis. Colorado State University.

Yamamoto H, Makita E, Oki Y, Otani M (2006) Flow characteristics and gelatinization kinetics of rice starch under strong alkali conditions. Food Hydrocoll. 20, 9-20

Yazaki Y, Collins PJ (1997) Uses of Wattle Extract: Tannin Based Adhesives. Rural Industries Research and Development Corporation. RIRDC Publication Nº 97/72. Chapter 15., pp 127-143. 


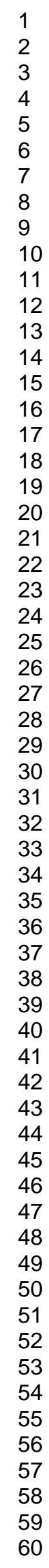

60 
Table 1

\begin{tabular}{c|c|c|c|c|c|c|c}
\hline $\begin{array}{c}\text { Number of } \\
\text { prepared } \\
\text { adhesives }\end{array}$ & $\begin{array}{c}\text { Total solids } \\
\text { content }(\%)\end{array}$ & $\begin{array}{c}\text { Sodium } \\
\text { hydroxide } \\
\text { concentration } \\
(\%)\end{array}$ & $\begin{array}{c}\text { Sodium } \\
\text { hydroxide/corn } \\
\text { starch volume } \\
\text { ratio }\end{array}$ & $\begin{array}{c}\text { Reaction } \\
\text { temperature } \\
\left({ }^{\circ} \mathrm{C}\right)\end{array}$ & $\begin{array}{c}\text { Reaction } \\
\text { time } \\
(\mathrm{min})\end{array}$ & $\begin{array}{c}\text { Shear } \\
\text { strength, } \\
(\mathrm{SD}), \text { MPa }\end{array}$ & $\begin{array}{c}\text { Veneer } \\
\text { Failure } \\
(\%)\end{array}$ \\
\hline 1 & 12 & 33 & 0.5 & 180 & 5 & $1.96(0.62)$ & 0 \\
2 & 25 & 33 & 0.5 & 180 & 5 & $2.32(0.11)$ & 0 \\
3 & 50 & 33 & 0.5 & 180 & 5 & $3.28(0.22)$ & 33 \\
4 & 65 & 33 & 0.5 & 180 & 5 & $3.76(0.11)$ & 66 \\
5 & 75 & 33 & 0.5 & 180 & 5 & $3.84(0.22)$ & 66 \\
6 & 90 & 33 & 0.5 & 180 & 5 & $3.88(0.39)$ & 66 \\
\hline
\end{tabular}


Table 2

\begin{tabular}{c|c|c|c|c|c|c|c}
\hline $\begin{array}{c}\text { Number of } \\
\text { prepared } \\
\text { adhesives }\end{array}$ & $\begin{array}{c}\text { Total } \\
\text { solids } \\
\text { content } \\
(\%)\end{array}$ & $\begin{array}{c}\text { Sodium } \\
\text { hydroxide } \\
\text { concentration } \\
(\%)\end{array}$ & $\begin{array}{c}\text { Sodium } \\
\text { hydroxide/corn } \\
\text { starch volume } \\
\text { ratio }\end{array}$ & $\begin{array}{c}\text { Reaction } \\
\text { temperature } \\
\left({ }^{\circ} \mathrm{C}\right)\end{array}$ & $\begin{array}{c}\text { Reaction } \\
\text { time } \\
(\mathrm{min})\end{array}$ & $\begin{array}{c}\text { Shear } \\
\text { strength, } \\
(\mathrm{SD}), \mathrm{MPa}\end{array}$ & $\begin{array}{c}\text { Veneer } \\
\text { Failure } \\
(\%)\end{array}$ \\
\hline 1 & 65 & 5 & 0.5 & 180 & 5 & $3.07(0.35)$ & 33 \\
2 & 65 & 15 & 0.5 & 180 & 5 & $3.32(0.16)$ & 33 \\
3 & 65 & 33 & 0.5 & 180 & 5 & $3.76(0.11)$ & 66 \\
4 & 65 & 50 & 0.5 & 180 & 5 & $3.42(0.07)$ & 33 \\
5 & 65 & 75 & 0.5 & 180 & 5 & $3.37(0.35)$ & 33 \\
\hline
\end{tabular}




\section{Table 3}

\begin{tabular}{c|c|c|c|c|c|c|c}
\hline $\begin{array}{c}\text { Number of } \\
\text { prepared } \\
\text { adhesives }\end{array}$ & $\begin{array}{c}\text { Total } \\
\text { solids } \\
\text { content } \\
(\%)\end{array}$ & $\begin{array}{c}\text { Sodium } \\
\text { hydroxide } \\
\text { concentration } \\
(\%)\end{array}$ & $\begin{array}{c}\text { Sodium } \\
\text { hydroxide/corn } \\
\text { starch volume } \\
\text { ratio }\end{array}$ & $\begin{array}{c}\text { Reaction } \\
\text { temperature } \\
\left({ }^{\circ} \mathrm{C}\right)\end{array}$ & $\begin{array}{c}\text { Reaction } \\
\text { time } \\
(\mathrm{min})\end{array}$ & $\begin{array}{c}\text { Shear } \\
\text { strength, } \\
(\mathrm{SD}), \mathrm{MPa}\end{array}$ & $\begin{array}{c}\text { Veneer } \\
\text { Failure } \\
(\%)\end{array}$ \\
\hline 1 & 65 & 33 & 0.2 & 180 & 5 & $3.25(0.30)$ & 33 \\
2 & 65 & 33 & 0.5 & 180 & 5 & $3.76(0.11)$ & 66 \\
3 & 65 & 33 & 0.8 & 180 & 5 & $2.93(0.16)$ & 33 \\
4 & 65 & 33 & 1.2 & 180 & 5 & $3.56(0.05)$ & 33 \\
5 & 65 & 33 & 1.5 & 180 & 5 & $3.44(0.11)$ & 0 \\
6 & 65 & 33 & 2 & 180 & 5 & $2.88(0.18)$ & 0 \\
\hline
\end{tabular}


Table 4

\begin{tabular}{c|c|c|c|c|c|c|c}
\hline $\begin{array}{c}\text { Number of } \\
\text { prepared } \\
\text { adhesives }\end{array}$ & $\begin{array}{c}\text { Total } \\
\text { solids } \\
\text { content } \\
(\%)\end{array}$ & $\begin{array}{c}\text { Sodium } \\
\text { hydroxide } \\
\text { concentration } \\
(\%)\end{array}$ & $\begin{array}{c}\text { Sodium } \\
\text { hydroxide/corn } \\
\text { starch volume } \\
\text { ratio }\end{array}$ & $\begin{array}{c}\text { Reaction } \\
\text { temperature } \\
\left({ }^{\circ} \mathrm{C}\right)\end{array}$ & $\begin{array}{c}\text { Reaction } \\
\text { time } \\
(\mathrm{min})\end{array}$ & $\begin{array}{c}\text { Shear } \\
\text { strength, } \\
(\mathrm{SD}), \text { MPa }\end{array}$ & $\begin{array}{c}\text { Veneer } \\
\text { Failure } \\
(\%)\end{array}$ \\
\hline 1 & 65 & 33 & 0.5 & 60 & 5 & $2.78(0.08)$ & 0 \\
2 & 65 & 33 & 0.5 & 80 & 5 & $2.84(0.16)$ & 0 \\
3 & 65 & 33 & 0.5 & 120 & 5 & $3.73(0.01)$ & 33 \\
4 & 65 & 33 & 0.5 & 140 & 5 & $4.20(0.16)$ & 33 \\
5 & 65 & 33 & 0.5 & 160 & 5 & $4.39(0.05)$ & 50 \\
6 & 65 & 33 & 0.5 & 170 & 5 & $4.54(0.02)$ & 66 \\
7 & 65 & 33 & 0.5 & 180 & 5 & $3.76(0.11)$ & 66 \\
8 & 65 & 33 & 0.5 & 200 & 5 & $3.5(0.54)$ & 50 \\
\hline
\end{tabular}




\section{Table 5}

\begin{tabular}{c|c|c|c|c|c|c|c}
\hline $\begin{array}{c}\text { Number of } \\
\text { prepared } \\
\text { adhesives }\end{array}$ & $\begin{array}{c}\text { Total } \\
\text { solids } \\
\text { content } \\
(\%)\end{array}$ & $\begin{array}{c}\text { Sodium } \\
\text { hydroxide } \\
\text { concentration } \\
(\%)\end{array}$ & $\begin{array}{c}\text { Sodium } \\
\text { hydroxide/corn } \\
\text { starch volume } \\
\text { ratio }\end{array}$ & $\begin{array}{c}\text { Reaction } \\
\text { temperature } \\
\left({ }^{\circ} \mathrm{C}\right)\end{array}$ & $\begin{array}{c}\text { Reaction } \\
\text { time } \\
(\mathrm{min})\end{array}$ & $\begin{array}{c}\text { Shear } \\
\text { strength, } \\
(\mathrm{SD}), \text { MPa }\end{array}$ & $\begin{array}{c}\text { Veneer } \\
\text { Failure } \\
(\%)\end{array}$ \\
\hline 1 & 65 & 33 & 0.5 & 170 & 1 & $3.03(0.12)$ & 25 \\
2 & 65 & 33 & 0.5 & 170 & 2 & $3.22(0.11)$ & 33 \\
3 & 65 & 33 & 0.5 & 170 & 4 & $4.49(0.30)$ & 66 \\
4 & 65 & 33 & 0.5 & 170 & 5 & $4.54(0.02)$ & 66 \\
5 & 65 & 33 & 0.5 & 170 & 7 & $3.81(0.21)$ & 66 \\
6 & 65 & 33 & 0.5 & 170 & 10 & $4.21(0.15)$ & 66 \\
7 & 65 & 33 & 0.5 & 170 & 15 & $3.94(0.28)$ & 66 \\
8 & 65 & 33 & 0.5 & 170 & 17 & $4.31(0.12)$ & 50 \\
9 & 65 & 33 & 0.5 & 170 & 20 & $4.19(0.13)$ & 33 \\
10 & 65 & 33 & 0.5 & 170 & 25 & $4.12(0.10)$ & 33 \\
\hline
\end{tabular}


Table 6

\begin{tabular}{|c|c|c|c|c|}
\hline Hardener & Tannin & Percentage of tannin $(\%)$ & $\begin{array}{c}\text { Shear strength, (SD), } \\
\mathrm{MPa}\end{array}$ & $\begin{array}{c}\text { Veneer failure } \\
(\%)\end{array}$ \\
\hline \multirow{14}{*}{$\begin{array}{c}5 \text { percent } \\
\text { hexamine by } \\
\text { weight on tannin } \\
\text { extract solids } \\
\text { content }\end{array}$} & \multirow{7}{*}{ Mimosa } & 0 & $4.49(0.30)$ & 66 \\
\hline & & 5 & $4.65(0.11)$ & 70 \\
\hline & & 10 & $5.21(0.05)$ & 85 \\
\hline & & 20 & $4.62(0.04)$ & 85 \\
\hline & & 30 & $4.19(0.26)$ & 70 \\
\hline & & 40 & $3.99(0.09)$ & 50 \\
\hline & & 50 & $3.53(0.20)$ & 35 \\
\hline & \multirow{7}{*}{ Quebracho } & 0 & $4.49(0.30)$ & 66 \\
\hline & & 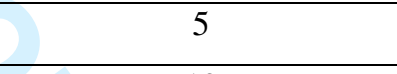 & $4.65(0.18)$ & 66 \\
\hline & & 10 & $5.00(0.12)$ & 75 \\
\hline & & 20 & $4.62(0.17)$ & 75 \\
\hline & & 30 & $4.14(0.19)$ & 50 \\
\hline & & 40 & $3.92(0.13)$ & 50 \\
\hline & & 50 & $3.50(0.16)$ & 35 \\
\hline
\end{tabular}


Table 7

\begin{tabular}{l|c}
\hline \multicolumn{1}{c|}{ Wood adhesives } & $\begin{array}{c}\text { Viscosity, Pa s } \\
\text { Mean } \pm \text { SD }\end{array}$ \\
\hline Cornstarch-NaOH & $61239 \pm 5045$ \\
Cornstarch-NaOH-MT-H & $45900 \pm 5840$ \\
Cornstarch-NaOH-QT-H & $47100 \pm 3010$ \\
\hline
\end{tabular}


Table 8

\begin{tabular}{l|c}
\hline \multicolumn{1}{c|}{ Wood adhesives } & $\begin{array}{c}\text { Shear strength, MPa } \\
\text { Mean } \pm \mathrm{SD}\end{array}$ \\
\hline Cornstarch-NaOH-MT-H & $5.21 \pm 0.05$ \\
Urea-formaldehyde & $5.87 \pm 0.15$ \\
Vinyl adhesive & $5.96 \pm 0.47$ \\
Polyurethane adhesive & $6.03 \pm 0.18$ \\
\hline
\end{tabular}


Table 9

\begin{tabular}{c|c|c|c|c}
\hline \multirow{2}{*}{$\begin{array}{c}\text { Vötsch climate } \\
\text { room conditions }\end{array}$} & \multicolumn{3}{|c}{ Shear strength, MPa; Mean \pm SD } \\
\cline { 2 - 5 } & $\begin{array}{c}\text { Cornstarch-NaOH- } \\
\text { MT-H }\end{array}$ & $\begin{array}{c}\text { Urea } \\
\text { formaldehyde }\end{array}$ & Vinyl adhesive & $\begin{array}{c}\text { Polyurethane } \\
\text { adhesive }\end{array}$ \\
\hline $25^{\circ} \mathrm{C}$ and $65 \%$ R.H & $5.21 \pm 0.05$ & $5.87 \pm 0.15$ & $5.96 \pm 0.47$ & $6.03 \pm 0.18$ \\
$25^{\circ} \mathrm{C}$ and $80 \%$ R.H & $5.35 \pm 0.11$ & $5.52 \pm 0.12$ & $5.91 \pm 0.19$ & $6.11 \pm 0.21$ \\
$25^{\circ} \mathrm{C}$ and 90\% R.H & $5.17 \pm 0.04$ & $5.51 \pm 0.09$ & $5.71 \pm 0.08$ & $5.87 \pm 0.06$ \\
\hline
\end{tabular}


Table 10

\begin{tabular}{l|c|c|c|c}
\hline & \multicolumn{3}{|c}{ Shear strength, MPa; Mean \pm SD } \\
\cline { 2 - 5 } & $\begin{array}{c}\text { Cornstarch-NaOH- } \\
\text { MT-H }\end{array}$ & $\begin{array}{c}\text { Urea } \\
\text { formaldehyde }\end{array}$ & Vinyl adhesive & $\begin{array}{c}\text { Polyurethane } \\
\text { adhesive }\end{array}$ \\
\hline Before immersion & $5.21 \pm 0.05$ & $5.87 \pm 0.15$ & $5.96 \pm 0.47$ & $6.03 \pm 0.18$ \\
After immersion & $1.07 \pm 0.24$ & $4.21 \pm 0.21$ & $4.93 \pm 0.33$ & $5.39 \pm 0.05$ \\
Retention (\%) & 21 & 71 & 83 & 89 \\
\hline
\end{tabular}




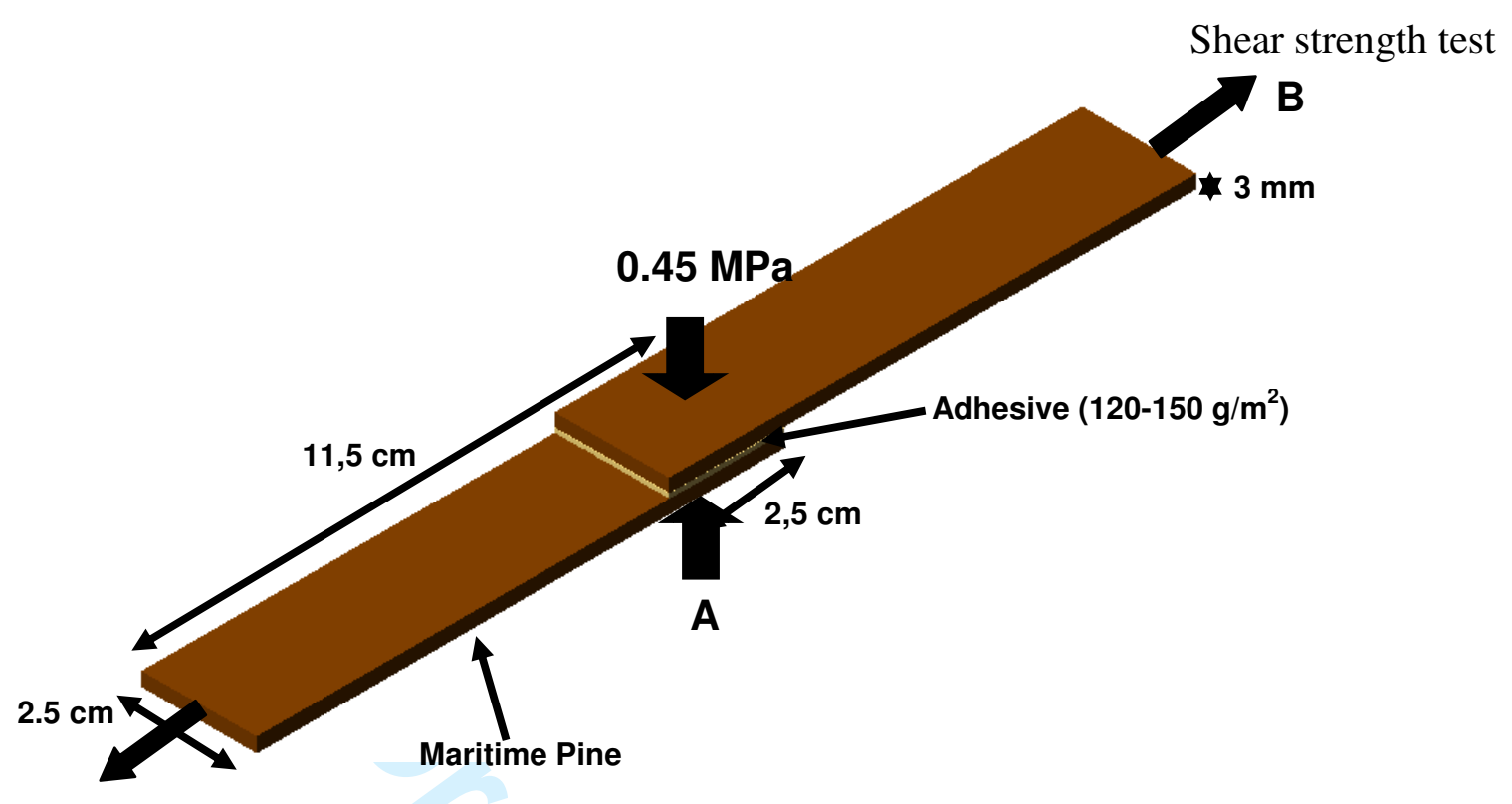

Fig. 1 


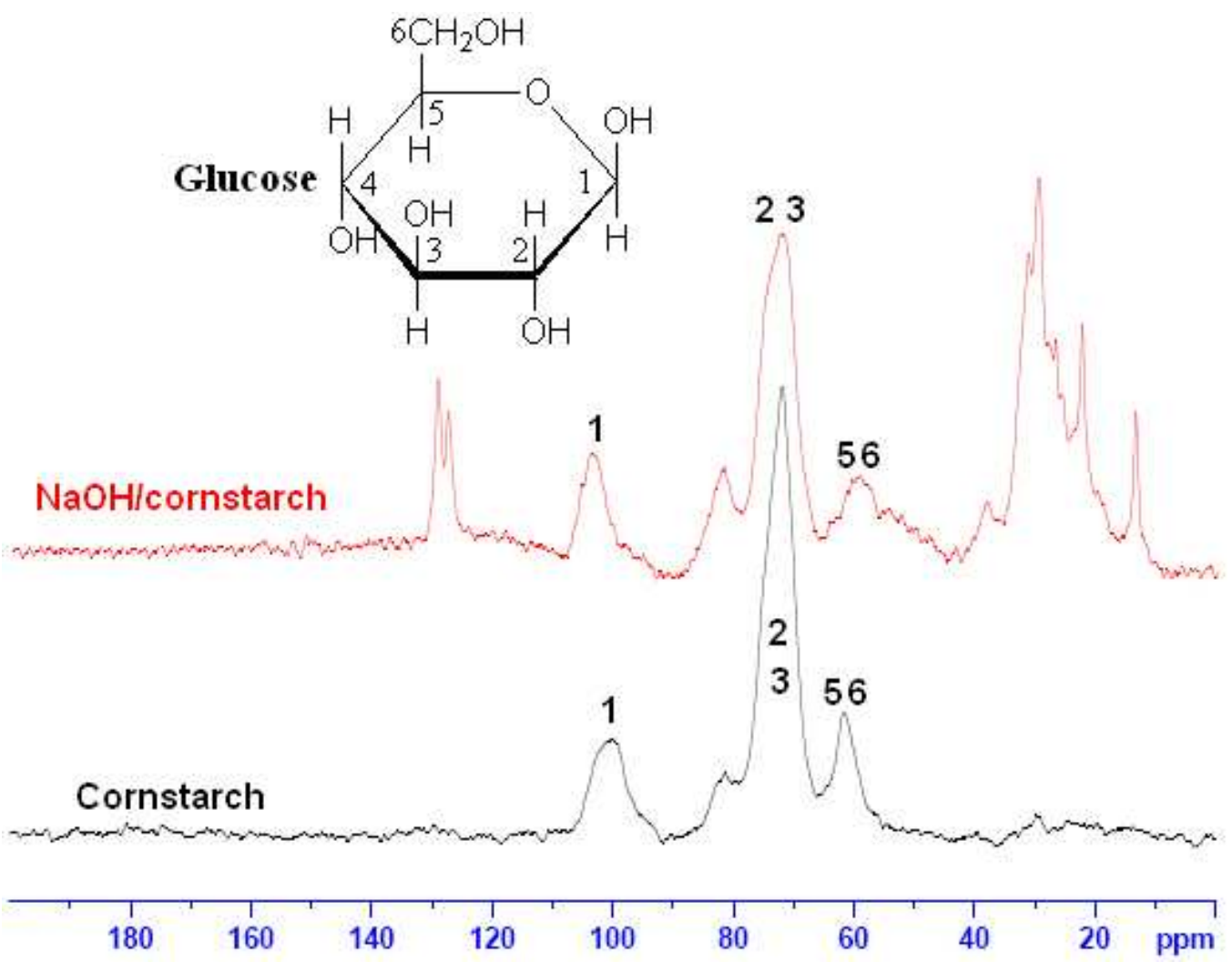

Fig. 2 


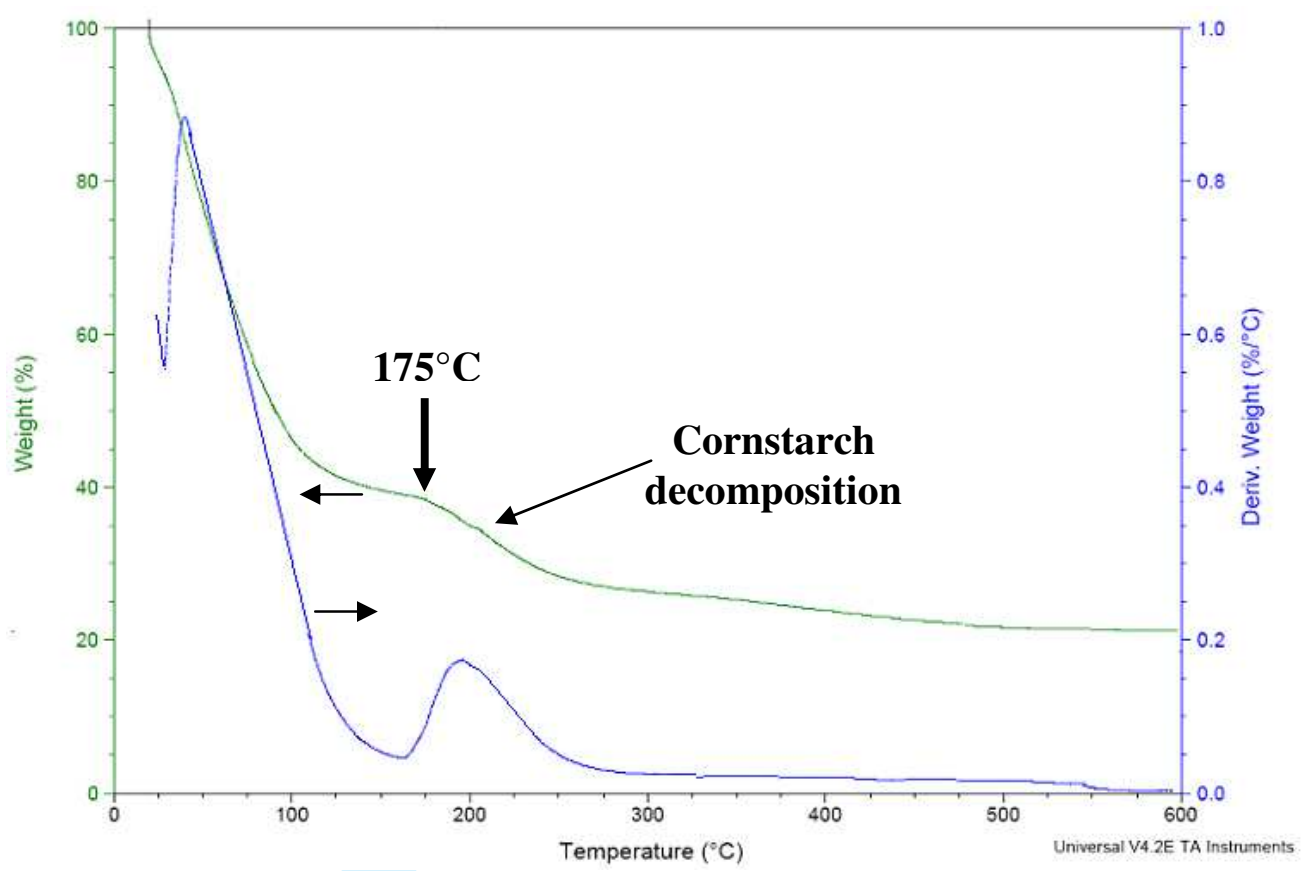

Fig. 3 


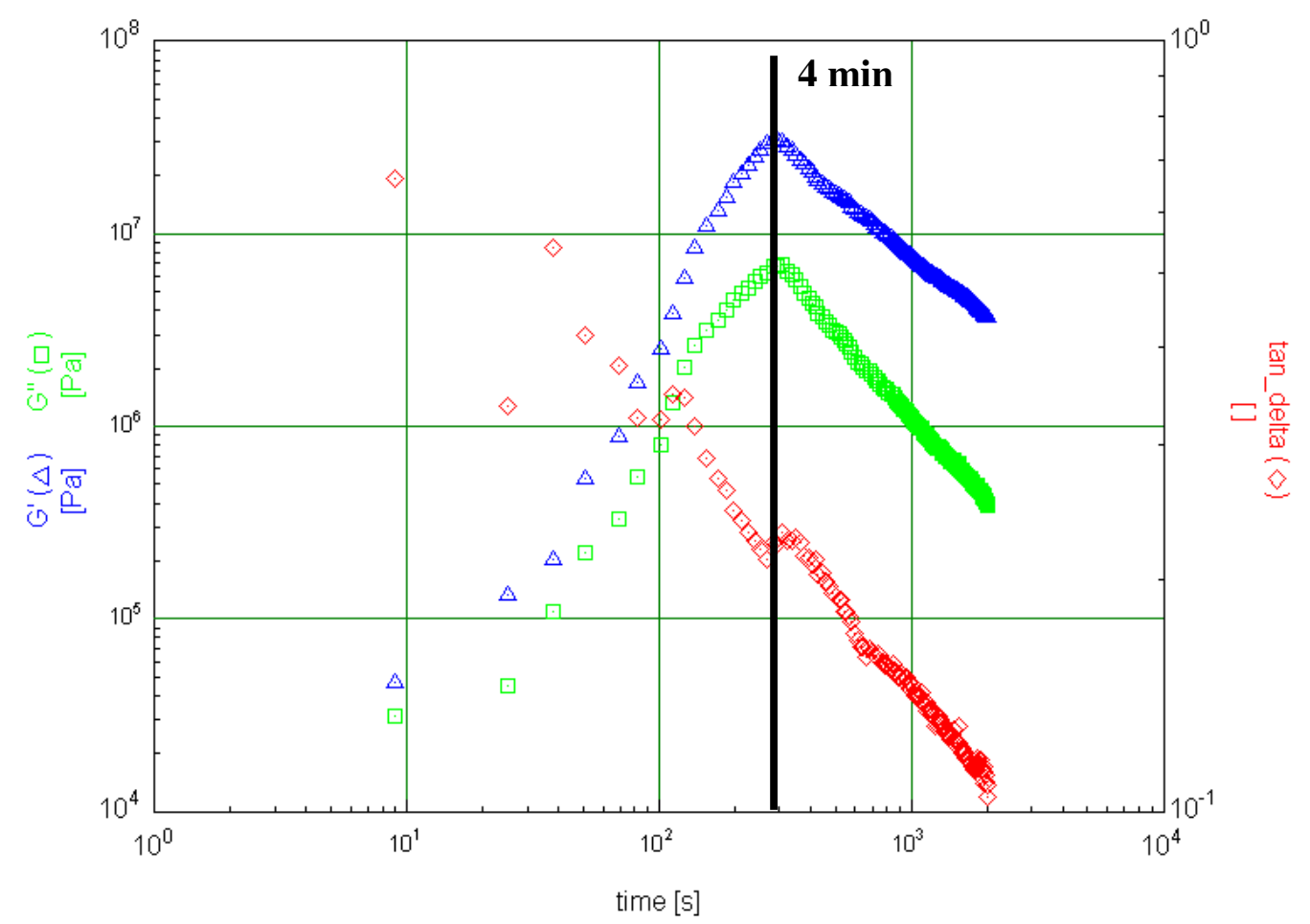

Fig. 4 
<smiles>Oc1cc(O)c2c(c1)OC(c1ccc(O)c(O)c1)CC2</smiles><smiles>C1CN2CN3CN1CN(C2)C3</smiles>

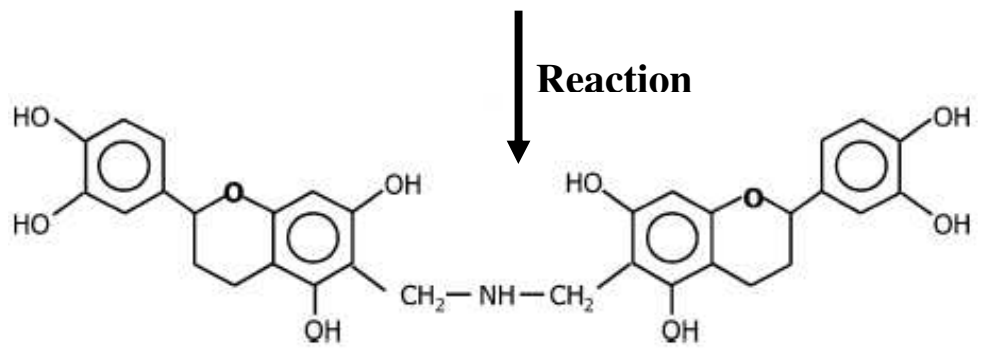

Fig. 5 


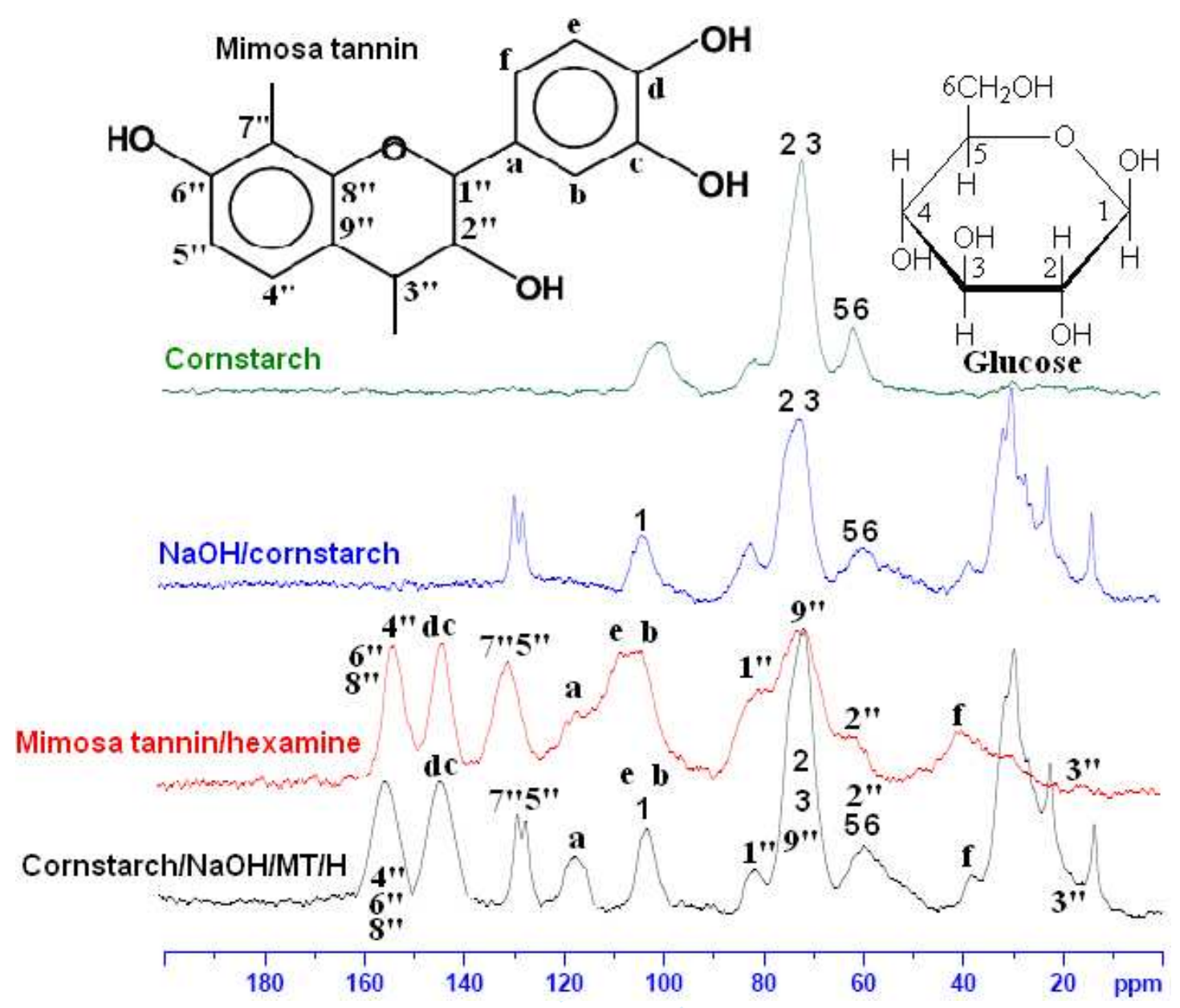

Fig. 6 


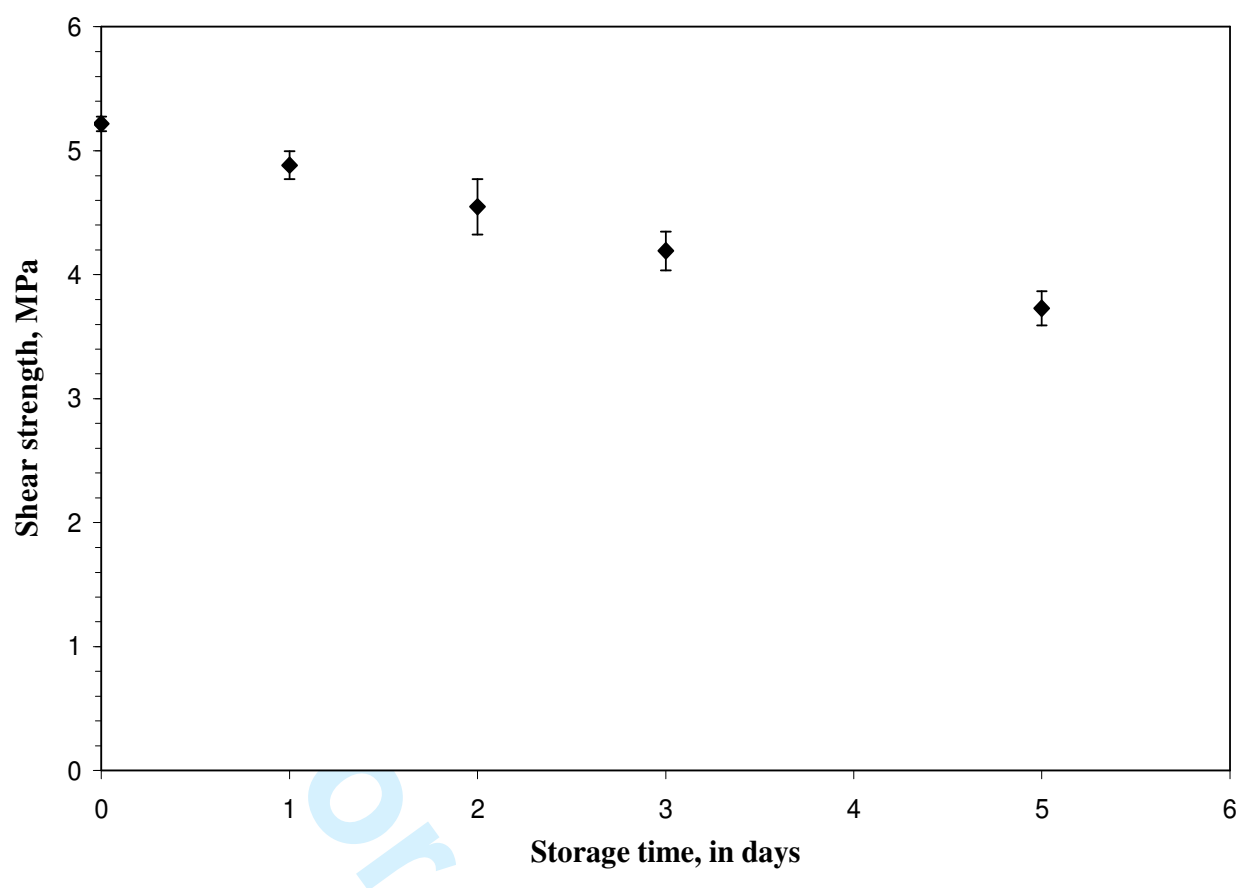

Fig. 7 
Table 1. Effects of total solids content of cornstarch-sodium hydroxide adhesives on shear strength (sodium hydroxide $(33 \%)$ /cornstarch volume ratio was fixed at the level $0.5 ; 0.45$ $\mathrm{MPa} ; 180^{\circ} \mathrm{C}$ and $\left.5 \mathrm{~min}\right)$. Ten replicates for each total solid content. SD: Standard deviation.

Table 2. Effect of sodium hydroxide concentration on shear strength (sodium hydroxide/cornstarch $(65 \%)$ volume ratio was fixed at the level $0.5 ; 0.45 \mathrm{MPa} ; 180^{\circ} \mathrm{C}$ and 5 min). Ten replicates for each $\mathrm{NaOH}$ concentration. SD: Standard deviation.

Table 3. Effects of sodium hydroxide/cornstarch volume ratio on shear strength (cornstarch (65\%), sodium hydroxide (33\%), $0.45 \mathrm{MPa} ; 180^{\circ} \mathrm{C}$ and $5 \mathrm{~min}$ ). Ten replicates for each sodium hydroxide/cornstarch volume ratio. SD: Standard deviation.

Table 4. Effects of hot-press temperature on shear strength (sodium hydroxide $(33 \%) /$ cornstarch $(65 \%)=0.5 ; 0.45 \mathrm{MPa}$ and $5 \mathrm{~min})$. Ten replicates for each hot-press temperature. SD: Standard deviation.

Table 5. Effects of hot-press time on shear strength (sodium hydroxide (33\%)/cornstarch $(65 \%)=0.5 ; 0.45 \mathrm{MPa}$ and $\left.170^{\circ} \mathrm{C}\right)$. Ten replicates for each hot-press time. SD: Standard deviation.

Table 6. Effects of tannin (Mimosa and Quebracho) and hexamine on shear strength at $170^{\circ} \mathrm{C}$ and 4 min. SD: Standard deviation.

Table 7. Results of viscosity of the three natural wood adhesives prepared under their optimal conditions at $25^{\circ} \mathrm{C}$.

Table 8. Mechanical properties of cornstarch-NaOH-MT-H adhesive and commercial adhesives.

Table 9. Shear strength values after 7 days in a Vötsch climate room $\left(25^{\circ} \mathrm{C} ; 65 \%, 80 \%\right.$ and $90 \%$ relative humidity). Ten replicates for each resin. SD: Standard deviation.

Table 10. Shear strength values before and after $2 \mathrm{~h}$ of immersion in water. Ten replicates for each resin. SD: Standard deviation. 
Figure 1. Schematic representation of wood sample preparation using cornstarch-tannin crosslinked adhesives. Step A: pressure at $180^{\circ} \mathrm{C}$ and $0.45 \mathrm{MPa}$, step B: shear strength test after 24 hrs in a Vötsch climate room $\left(25^{\circ} \mathrm{C}\right.$ and $65 \%$ humidity).

Figure 2. Comparative solid state CP-MAS ${ }^{13} \mathrm{C}$ NMR spectra of cornstarch and $\mathrm{NaOH} /$ cornstarch.

Figure 3. TGA and DTG curves of cornstarch-NaOH adhesives, $\beta=5^{\circ} \mathrm{C} / \mathrm{min}$.

Figure 4. Time evolution of storage modulus (G') and loss modulus (G',) of cornstarch$\mathrm{NaOH}$ adhesive at $25^{\circ} \mathrm{C} ; 1 \mathrm{rad} / \mathrm{s}$ and $1 \%$.

Figure 5. Schematic diagram of the reaction between tannin and hexamine.

Figure 6. Comparative solid state $\mathrm{CP}-\mathrm{MAS}{ }^{13} \mathrm{C}$ NMR spectra of cornstarch, $\mathrm{NaOH} /$ cornstarch, mimosa tannin/hexamine and cornstarch/NaOH/MT/H.

Figure 7. Effects of storage time of the cornstarch-NaOH-MT-H adhesive on shear strength.

Tabelle 1

Einfluss des Gesamt-Feststoffgehalts des Maisstärke-Natriumhydroxid-Klebstoffs auf die Scherfestigkeit (Natriumhydroxid (33\%)/ Maisstärke Volumenverhältnis 0,5;0,45 MPa; $180^{\circ} \mathrm{C}$ und 5 Minuten). Zehn Proben je Gesamtfeststoffgehalt. SD: Standardabweichung

Tabelle 2

Einfluss der Natriumhydroxidkonzentration auf die Scherfestigkeit (Verhältnis von Natriumhydroxid/Maisstärke $(65 \%)=0,5 ; 0,45 \mathrm{MPa} ; 180^{\circ} \mathrm{C}$ und 5 Minuten). Zehn Proben je Natriumhydroxidkonzentration. SD Standardabweichung

Tabelle 3

Einfluss des Volumenverhältnisses von Natriumhydroxid und Maisstärke auf die Scherfestigkeit (Maisstärke 65\%, Natriumhydroxid 33\%; 0,45 $\mathrm{MPa} ; 180^{\circ} \mathrm{C}$ und 5 Minuten). Zehn Proben je Natriumhydroxid/Maisstärke Volumenverhältnis. SD Standardabweichung.

Tabelle 4

Einfluss der Temperatur beim Heißpressen auf die Scherfestigkeit (Natriumhydroxid 33\%/Maisstärke 65\%Volumenverhältnis 0,5; 0,45 MPa und 5 Minuten. Zehn Proben je Presstemperatur, SD Standardabweichung

Tabelle 5 
Tabelle 6

Einfluss von Tannin (Mimosa und Quebracho) und Hexamin auf die Scherfestigkeit bei $170^{\circ} \mathrm{C}$ und 4 Minuten. SD: Standardabweichung

Tabelle 7

Viskosität der drei unter optimalen Bedingungen hergestellten natürlichen Holzklebstoffe bei $25^{\circ} \mathrm{C}$

Tabelle 8

Mechanische Eigenschaften von Maisstärke-NaOH-MT-H Klebstoff und handelsüblichen Klebstoffen

Tabelle 9

Scherfestigkeit nach siebentägiger Lagerung in einem Vötsch Klimaraum $\left(25^{\circ} \mathrm{C}, 65 \%, 80 \%\right.$ und 90\% rel. Luftfeuchte). Zehn Proben je Harz. SD Standardabweichung

Tabelle 10

Scherfestigkeit vor und nach 2-stündiger Wasserlagerung. Zehn Proben je Harz. SD

Standardabweichung

Abb. 1

Schematische Darstellung der Herstellung der Prüfkörper mit quervernetzten MaisstärkeTannin-Klebstoffen. Schritt A: Pressdruck 0,45 MPa bei $180^{\circ} \mathrm{C}$, Schritt B:

Scherfestigkeitsversuch nach 24-stündiger Lagerung im Vötsch Klimaraum $\left(25^{\circ} \mathrm{C}\right.$ und $65 \%$ Luftfeuchte)

Abb. 2

Festkörper-CP-MAS ${ }^{13}$ CNMR Referenzspektrum von Maisstärke und NaOH/Maisstärke

Abb. 3

TGA und DTG Kurven der Maisstärke-NaOH-Klebstoffe, $\beta=5^{\circ} \mathrm{C} / \mathrm{min}$

Abb. 4

Zeitlicher Verlauf des Speichermoduls (G`) und Verlustmoduls (G`') des Maisstärke-NaOHKlebstoffs bei $25^{\circ} \mathrm{C}$; $1 \mathrm{rad} / \mathrm{s}$ und $1 \%$.

Abb. 5

Schematische Darstellung der Reaktion zwischen Tannin und Hexamin.

Abb. 6

Festkörper-CP-MAS ${ }^{13}$ CNMR Referenzspektrum von Maisstärke und NaOH/Maisstärke, Mimosatannin/Hexamin und Maisstärke/NaOH/MT/H

Abb. 7 
Einfluss der Lagerungsdauer von Maisstärke-NaOH-MT-H Klebstoffen auf die Scherfestigkeit 